This item was submitted to Loughborough's Research Repository by the author.

Items in Figshare are protected by copyright, with all rights reserved, unless otherwise indicated.

\title{
Perceived organizational support, internal motivation, and work-family conflict among soccer referees
}

PLEASE CITE THE PUBLISHED VERSION

https://doi.org/10.1080/23750472.2019.1593049

\section{PUBLISHER}

(c) Taylor \& Francis

\section{VERSION}

AM (Accepted Manuscript)

\section{PUBLISHER STATEMENT}

This is an Accepted Manuscript of an article published by Taylor \& Francis in Managing Sport and Leisure on 22 Mar 2019, available online: https://doi.org/10.1080/23750472.2019.1593049

\section{LICENCE}

CC BY-NC-ND 4.0

\section{REPOSITORY RECORD}

Hong, Eunah, Yejee Jeong, and Paul Downward. 2019. "Perceived Organizational Support, Internal Motivation, and Work-family Conflict Among Soccer Referees". figshare. https://hdl.handle.net/2134/37632. 


\title{
Perceived Organizational Support, Internal Motivation, and Work-Family Conflict
}

\section{Among Soccer Referees}

\begin{abstract}
This study explores the perceived organizational support, internal motivation, and work-family conflict of amateur soccer referees of South Korea. The aim is to inform effective strategies for the retention of referees, which is necessary for the sport to function. Past research has addressed perceived organizational support, internal motivation, and work-family conflict, but does not integrate these three domains. We collected data from 260 referees and used structural equation modeling to test hypotheses. The findings of this study are as follows: First, perceived organizational support had a positive effect on internal motivation. Second, internal motivation reduced work- family conflict. Third, internal motivation fully mediated the relationship between perceived organizational support and work-family conflict. The practical implications for more effective human resource management are discussed in depth and include providing network opportunities for referees, and also constructive feedback from interactions between referees and their coaches.
\end{abstract}

Keywords: Perceived Organizational Support, Internal Motivation, Work-Family Conflict, Soccer Referees, South Korea

\section{Introduction}

The role of referees in sport is essential as they enforce the rules of the game as a neutral party (Rullang, Emrich, \& Pierdzioch, 2017). As Cunningham and Simmons (2014) argue, referees are an integral part of sports who both improve the game as well as ensure the safety of participants. It is important to engage referees in sporting competitions since their authority greatly enhances the quality of play and the spectator experience (Cuskelly \& Hoye, 2013). In general, being in the spotlight is not always positive for referees: they tend to become the focus of anger for players, coaches, and fans, especially in soccer (Parsons \& Bairner, 2015). The growth of broadcasting fees associated with the media coverage of soccer, coupled with the introduction and enhancement of technological scrutiny of the game has intensified criticism towards referees (Buraimo, Forrest, \& Simmons, 2010; Webb, 2018).

In any organization, the recruitment, retention, and low turnover of quality personnel are critical to its smooth functioning (MacIntosh \& Doherty, 2010; Voorde, Veldhoven, \& Paauwe, 2010). In the context of 
referees in sport, governing bodies must not only recruit new personnel, but also try to minimize the average drop-out rates by improving training and organizational support (Cuskelly \& Hoye, 2013). Despite such efforts, it is reported that several countries suffer from a lack of referees across sports (Auger, Fortier, Thibault, Magny, \& Gravelle, 2010; Kim, 2016).

In the case of Korean soccer, the shortage of referees has already been exacerbated by the introduction of the Weekend League, which launched in 2009 by the Korea Football Association (KFA), the Ministry of Culture, Sports and Tourism and the Ministry of Education. Prior to the Weekend League, centralized competitions for elementary, middle and high school students ran through the year even in school term times, which deprived student athletes of academic opportunity (Korea Football Association, 2018a). According to the KFA (2018a), 576 teams participated in 2009 and the number reached 750 in 2018. Having increased the number of matches, the majority of Regional Football Associations (RFA) reported that they struggle to appoint the appropriate number of referees to the matches. Not only had RFA to invite referees from other RFA, but they also had to appoint referees who are not eligible for the specific match due to shortage of referees (Korea Football Association, 2018b). The number of registered referees in the KFA is 7,482. However, the number of active referees is 2,590 , which is just over a half of the total registered pool and not sufficient to cover the increased number of matches (Korea Football Association, 2018b).

Recent studies of soccer referees in sport have focused mainly on the decision-making (Berrar, Lopes, \& Dubitzky, 2017; Nevill, Hemingway, Greaves, Dallaway, \& Devenport, 2017; Soares \& Shamir, 2016) and passion-related motives (Johansen, 2015; Ridinger, Warner,Tingle, \& Kim, 2017; Rullang et al., 2017). In a study conducted by Kim and Hong (2016), retired Korean female referees were asked about the experiences that had led them to quit soccer. Among the reasons they gave for dropping out, work-family conflict and a lack of administrative support were notable. Work-family conflict is a characteristic of most referees' lives and organizational support could be considered to improve conditions for them and mitigate their work-family conflict (Cuskelly \& Hoye, 2013; Kim, 2016). For example, some referees have control over their schedules, which may alleviate a significant amount of work-family conflict, while others have a fixed work schedule including significant travel and training. According to Ridinger et al. (2017), travel and game time conflicting with job schedules were the second highest reasons followed by physical limitation for discontinued involvement officiating.

As with the general work environment, the majority of referees are engaged in multiple roles alongside that of referee, such as bread winner, parent, or student. Due to these multiple demands, referees are likely to 
experience some degree of work-family conflict. In a refereeing setting, work-family conflict can be understood either from a physical perspective, since a referee cannot physically attend a family gathering and a soccer match simultaneously, or from a psychological perspective, since domestic troubles may prevent them from concentrating at work.

Studies well document the negative impact of work-family conflict on the individual (Dixon \& Bruening, 2005; Frone, Russell, \& Copper, 1992; Greenhaus \& Beutell, 1985; Vernon, 2013). Nevertheless, there has been little attempt to investigate the processes that cause work-family conflict in the case of soccer refereeing. Therefore, it is worth investigating the potential role that perceived organizational support plays in reducing work-family conflict. This investigation coupled with the examination of internal motivation as a mediating factor distinguishes this study from its predecessors.

\section{Theoretical Background and Hypothesis Development}

\subsection{Perceived Organizational Support and Internal Motivation}

Originating in organizational support theory (Eisenberger, Huntington, Hutchison, \& Sowa, 1986), perceived organized support is based on social exchange theory. According to social exchange theory (Blau, 1964; Gouldner, 1960), employees who perceive that they are supported by their organization tend to value it more and actively collaborate to achieve its goals (Eisenberger et al., 1986).

Organizational support theory draws on social exchange theory to explain this kind of employeeorganization relationship. Eisenberger et al. (1986) defined perceived organizational support as "global beliefs developed by employees concerning the extent to which the organization values their contributions and cares about their well-being"(p. 501). According to perceived organizational support, one way employees repay their organization for its greater support is to exhibit positive attitudes to their job, display cooperative organizational behaviors (Loi , Hang-Yue, \& Foley, 2006) or dedicate themselves to their work and the organization.

Internal motivation is said to occur when people do something because it brings them genuine pleasure or they believe it is significant (Cordova \& Lepper, 1996; Ryan \& Deci, 2000a). The term "internally motivated" indicates a highly autonomous state of motivation derived from the inherent satisfaction, enjoyment, or challenge a task delivers (Gagné, Ryan, \& Bargmann, 2003; Gillet, Vallerand, Amoura \& Baldes, 2010).

With regard to soccer referees, only a few studies have considered the importance of internal motivation. A separate study conducted on Canadian referees by Auger et al. (2010) revealed that "the love and passion of 
the sport" ranked as the highest motivating factor that encouraged referees to begin officiating. Philippe, Vallerand, Andrianarisoa, and Brunel (2009) also stressed that officials are often highly passionate about refereeing, and their level of enthusiasm is often higher than that of athletes.

If that is the case, how can organizations improve internal motivation? According to Demerouti (2006) and Vallerand (1997), internal motivation is not only an intrapersonal phenomenon, but also a social phenomenon that includes job characteristics and organizational environment. Demerouti (2006) showed that positive work-related experiences have a positive effect on intrinsic work motivation and Vallerand $(1997,2007)$ demonstrated that motivation at an individual level is influenced by social factors in the domain of sport. Encouraging a favorable organizational environment (Lamm, Tosti-Kharas, \& King, 2014) and improving the level of trust between the organization and its employees (Seibert, Wang, \& Courtright, 2011) are the variables that have been found to most increase employees' sense of motivation and psychological empowerment.

Since perceived organizational support makes employees feel more related to the organization (Wu \& Liu, 2014), it is likely to make them feel more autonomous at work. perceived organizational support can also provide employees with the resources necessary to perform their job more efficiently and make them feel more competent and motivated (Mitchell, Gagné, Beaudry, \& Dyer, 2012; Seibert et al., 2011). The following hypothesis has, thus, been proposed:

\section{Hypothesis 1. Perceived organizational support will have a positive effect on the internal motivation of referees of Korean soccer.}

\subsection{Internal Motivation and Work-Family Conflict}

Work-family conflict is defined as "a form of inter-role conflict in which the role pressures from the work and family domains are incompatible in some respect"(Greenhaus \& Beutell, 1985, p. 77). This needs to be considered from both a work-family conflict (work troubles being caused by family life) and a familywork conflict (family troubles being caused by work) perspective because the two domains are not always coincident (Greenhaus \& Beutell, 1985). It is now usually accepted that the conflict between work and family is bidirectional (Frone et al., 1992; Greenhaus \& Beutell, 1985).

Recent studies have gone beyond the conflict view of the work and family relationship and tried instead to see the two domains as somehow integrated (Clark, 2000; Greenhaus, Collins, \& Shaw, 2003). However, in reality, personal resources are finite and role demands inevitably clash. Previous studies have reported that employees are still distressed because of time, strain, and behavior-based conflict (Barnett, 2004; 
Greenhaus \& Beutell, 1985).

It has also been widely reported that work-family conflict has adverse effects on both family life and the work environment, impacting the well-being of society as a whole. For example, in a study of 215 dual-income families in Finland, Mauno and Kinnunen (1999) reported that work-family conflict was one of the major stressors affecting couples' marital satisfaction. Many studies have suggested that inability to manage work-family conflict can lead to negative consequences, such as lower job satisfaction, and poor performance outcomes (Duong, Tuckey, Hayward, \& Boyd, 2015). Therefore, it is worth examining work-family conflict as an outcome variable.

The situation is no different in Korea. As a representative example of a collectivist society, Korea has historically valued group harmony (Lim, Song, \& Choi, 2012). In the collectivist Korean climate, people tend to value group goals more highly than their personal goals since they do not want their personal issues to disrupt the harmony of the group (Kim, 2014). Korean workers therefore often fail to separate their personal lives from work, and the conflict between their family and work duties can impose a burden on them, putting them under severe stress.

Séguin-Lévesque, Laliberté, Pelletier, Blanchard, and Vallerand (2003) have shown that people with a low level of internal motivation not only tend to experience more interpersonal conflicts due to the way they manage their activities, but also more conflicts between their work activity and other life domains. By contrast, highly motivated members will exhibit more control in the performance of their tasks, deploying their abilities in order to enhance both the organization's effectiveness as well as the quality of their own life (Chaturvedi, 2008). Although internal motivation may differ depending on work cultures and job requirements, personal values and internal flow are central to organizing meaning and action for working people (Carlson \& Kacmar, 2000). Therefore, it makes sense to examine the role of internal motivation in relation to work-family conflict, and the following hypothesis is proposed:

Hypothesis 2. Increasing the internal motivation of referees of Korean soccer will reduce work-family conflict.

\subsection{The Mediating Role of Internal Motivation between Perceived Organizational Support and Work-Family Conflict}

This study assumes that internal motivation mediates the relationship between perceived organizational support and work-family conflict. Studying five partner hospitals in a large Canadian city, Mitchell et al. (2012) 
showed that perceived organizational support was related to increased motivation and intrinsic motivation was found to mediate the effects of perceived organizational support on attitudes: when employees felt that their organization valued and respected them, they enjoyed using the organizational system more and were more inclined to accept new organizational policies. The study indicates, therefore, that employees feel intrinsically motivated when they perceive support from their organization (Eaton, 2003; Mitchell et al., 2012).

It is also worth noting that a few studies have raised the role of the mediating process perceived organizational support must pass through to achieve effectiveness. For example, research conducted by Cuskelly and Hoye (2013) revealed that perceived organizational support had no significant influence on sporting officials' intention to continue in their role. The authors pointed out that there should be mediator accounting for the variance, and the mediator could be internal motivation. Vallerand (2007) also investigated motivational processes in the sporting and physical activities of athletes and found that social and environmental impact on individual motivation occurs through a causal chain of processes. Social and environmental factors have a positive effect on consequences through intrinsic motivation. Of course, while the social factors such as the organizational climate including perceived organizational support, or the coach's behavior would vary, their impact on various positive outcomes would depend first on the impact on internal motivation (Pelletier, Fortier, Vallerand, \& Briere, 2001; Vallerand, 2007).

In turn, people who perceive organizational factors more positively would be more intrinsically motivated and feel strong associations with what they do, even if it is energy- and time-consuming, which minimizes any perceived conflict (Ramos, Brauchli, Bauer, Wehner, \& Hammig, 2015). Hence, the following hypothesis is proposed:

\section{Hypothesis 3. The internal motivation of referees of Korean soccer will mediate the relationship} between perceived organizational support and work-family conflict.

\section{Methodology}

\subsection{Sample and Procedure}

In order to collect the data, we initially contacted the refereeing department at the KFA and explained the purpose of the study. Having acquired permission from the senior officials at the KFA, a survey questionnaire was sent by special post to national soccer venues across the country where national tournaments were being held. In national tournaments which still exist, especially in the school summer vacation period, a group of twenty to forty amateur referees stay in a designated place together accompanied by a few assessors. 
The first author of this study, a former FIFA referee, contacted the referee assessors by phone and provided some additional information to supplement the written instructions enclosed in the survey. The researcher asked the assessors to play a "survey distribution" role only and not to screen whether the surveys were fully completed, but simply to return them by post. The researcher distributed a total of 300 surveys to eight separate competitions, 282 surveys were returned and 22 surveys were excluded for being incomplete. The sample for the final data analysis was 260 , of which $88.5 \%$ (231) were male, $58.6 \%$ (153) were married, and $25.4 \%$ were in their 30s (average age 33.69).

\section{2 Measurements}

All items were measured on a 7 -point Likert scale ( $1=$ strongly disagree to $7=$ strongly agree). We collected data from the referees regarding their perceived organizational support, internal motivation, and work-family conflict. In order to ensure the equivalence of the measures in the Korean and English versions, all of the scales were translated into Korean and then back-translated into English.

We defined perceived organizational support as the global beliefs about the extent to which the organization values referees' contributions and cares about their well-being and 10 items were adopted from Eisenberg, Huntington, Hutchison, and Sowa (1986). Sample items included "the association strongly considers my goals and values," and "the association fails to appreciate any extra effort from me (reverse)."

Internal motivation was defined as the level of an individual's desire to seek out new challenges, to be competent and self-determining, and to gain new knowledge. 7 items were adopted from Clary, Snyder, Ridge, Copeland, Stukas, Haugen, and Meine (1998)1. Sample items included "I referee because it makes me feel like an important human being," and "I referee because it enables me to do something important."

Work-family conflict was defined as the perception of any conflict or strain created by the incompatibility between work and life or life and work responsibilities. In other words, although we use the term work-family conflict, we deal with both conflicts in which the general demands of the job interfere with family-related responsibilities and conflicts in which the general demands of the family interfere with work-related ones. 9 items were adopted from Netemeyer, Boles, and McMurrian (1996). Sample items included "refereeing activity interferes with my family life," "refereeing activity affects my home duties negatively and triggers tense situations," and "requirements from home interfere with my refereeing activity."

1 As no scale was found to measure referees' motivation, we searched for an alternative one. We noted Clary et al.'s (1998) study in which volunteers are defined to be people who actively look for chances to help others and spend substantial amounts of time and energy on the activity. Also, in Cuskelly's (2004) study, volunteers were defined as those who participated in "roles undertaken to support, and/or run organized sport and physical activity" (Australian Bureau of Statistics, 2002: 39) and clarified that referees are included as volunteers. 
In addition, we controlled for other variables such as sex, age, education level, career year, income, marital status, number of matches per month, and the level at which referees were performing to reduce the effect of potential predictors of motivation and outcome variables. Concerning age, career year and level, more qualified officials may have greater levels of work-family conflict or stress. Meanwhile, studies have consistently found that income is a pivotal factor for family life. Low income is one of many established risk factors for family breakdown (Mitchell, 2013), so both income from refereeing and income excluding refereeing fee were included as control variables.

\section{3 Analytical Procedure}

The data were gathered through the self-reporting of referees so we had to mitigate the effect of using a common source as much as possible. In order to achieve this, a LISREL Confirmatory Factor Analysis (CFA; Jöreskog \& Sorbom, 1993) was conducted to verify the fit of the hypothesized three-factor (perceived organizational support, internal motivation, and work-family conflict) model. Most researchers agree that common method bias is a potential problem in survey-based studies so we conducted Harman's single-factor test, as suggested by Podsakoff, MacKenzie, Lee, and Podsakoff (2003). Using this technique, a single-factor model was compared to a multiple-factor one. In the single-factor model, we included all question items from the constructs in this study to determine whether the majority of the variance could be accounted for by one general factor. In the multiple-factor model, on the other hand, we allocated the items to three constructs or factors: perceived organizational support items to A, internal motivation to $\mathrm{B}$, and work-family conflict to $\mathrm{C}$.

The CFA results are summarized in Table 1. They show that the hypothesized three-factor model fit the data reasonably well. The chi-square and fit indexes were $\chi^{2}=1867.10, d . f .=272$; comparative fit index $(\mathrm{CFI})=0.92$, normed fit index $(\mathrm{NFI})=0.91$, comparative fit index $(\mathrm{CFI})=0.92$, incremental fit index $(\mathrm{IFI})=$ 0.92 , and standardized root mean square residual $(\mathrm{SRMR})=0.12$. These results indicated a good fit and supported the use of a multi-factor model for this study. All factor loadings were significant $(p<0.001)$ and greater than 0.50 (Hair, Anderson, Tatham, \& Black, 1992); they ranged from 0.62 to 0.82 for perceived organizational support, from 0.66 to 0.77 for internal motivation, and from 0.61 to 0.81 for work-family conflict. By contrast, the one-factor model gave a poor fit and so it is unlikely that the one-factor model fits the data $\left(\chi^{2}=\right.$ 8891.80, $d . f .=275, \mathrm{NFI}=0.71, \mathrm{CFI}=0.72, \mathrm{GFI}=0.43$ ). Therefore, we determined the hypothesized three-factor model to be a better fit and confirmed its discriminant validity. 


\section{Results}

\subsection{Descriptive Statistics}

\section{$<$ Table 2 about here $>$}

\section{$<$ Table 3 about here $>$}

Table 2 shows descriptive statistics and reliability for the main constructs measured in this study and Table 3 shows the means and standard deviations for each control variable. All the scales of the three main variables demonstrated adequate and acceptable levels of reliability over 0.70 (Nunnally \& Bernstein, 1994). The patterns of correlation among the theoretical variables were congruent with the hypotheses of this study.

\subsection{Hypothesis Testing}

The research model was compared with an alternative model, the partial mediating model. The full mediating model we chose as the research model differs from the partial mediating model because the direct path from perceived organizational support to work-family conflict is reduced in the full mediating model. First, a model that excluded a path from perceived organizational support to work-family conflict was tested. This model showed a good fit for the data; IFI, CFI, NFI, and GFI were all above the recommended level $\left(\chi^{2}=.87\right.$, $d . f .=1, \mathrm{IFI}=1.00, \mathrm{CFI}=1.00, \mathrm{NFI}=1.00, \mathrm{GFI}=1.00)$, indicating a good model fit (Hair et al., 1992; Mulaik, James, Alstine, Lind, \& Stilwell, 1989). Next, a partial mediating model including a direct path from perceived organizational support to work-family conflict was tested to determine whether partial mediation was at play. This model also revealed a good model fit; however, perceived organizational support did not have a direct effect on work-family conflict (-0.06, N.S.). Therefore, the full model was more parsimonious and represented a better fit for the data than the partial mediating model. None of the control variables except 'current level of refereeing' was associated with the study variables $(.15, p<0.10)$. In the analysis, the level of refereeing had a marginal but positive effect on work-family conflict: Referees are supposed to be assigned higher level of games as they ascend the promotion ladder. Referees at a higher level tend to travel more as their matches are held across the country rather than locally and this would lead to increased work-family conflict. 
Hypothesis 1 predicted that perceived organizational support would have a positive effect on the internal motivation of referees. Supporting this hypothesis, perceived organizational support increased internal motivation significantly: $\beta=0.32, p<0.001$. As predicted by Hypothesis 2 , a high level of internal motivation had a significantly negative effect on work-family conflict: $\beta=-0.28, p<0.001$. Finally, Hypothesis 3 predicted that internal motivation would mediate the relationship between perceived organizational support and work-family conflict and, as mentioned above, internal motivation fully mediated the relationship.

To verify the mediation effect again, the Sobel test (Sobel, 1982) was conducted, which showed that z-values were significant: $z=-2.91, p<0.001$. These results confirmed that the effect of perceived organizational support on work-family conflict was fully mediated by internal motivation.

\section{Discussion}

In the data collected from 260 soccer match referees in Korea, all the hypotheses were supported. We will now discuss these results in further detail in terms of their academic and practical implications.

First, with respect to perceived organizational support's positive influence on the internal motivation of referees, the results indicate that the individual referees felt more intrinsically motivated when they perceived that the KFA or RFA valued and appreciated them. The findings of this study support the work of Vallerand (1997), demonstrating that motivation can result both from differences in environmental and individual factors. In particular, this study focused on environmental factors, revealing that positively perceived organizational situations improve referees' internal motivation (Gagné \& Deci, 2005; Vallerand, 1997). The research by Gagné, Forest, Gilbert, Aube, Morin, and Malorni (2010) showed that perceived organizational support was strongly and positively linked to internal motivation, a view supported by the results. The results are also consistent with those of Tremblay, Blanchard, Taylor, Pelletier, and Villeneuve's study (2009), who proved that perceived organizational support positively predicted internal motivation and highlighted the importance of social factors as a motivational determinant.

The results of this study have some managerial implications, suggesting approaches that may increase perceived organizational support in the Korean soccer refereeing context. It is worth considering whether the KFA needs to provide funding for and require that RFA run seminars on a regular basis. Interaction among referees of different levels at a single location could provide an opportunity for all referees to share their emotional difficulties and practical challenges, as well as to improve working relations with other colleagues 
(Hong \& Kim, 2013). The impact of peer interaction and support programs has been demonstrated by previous studies. For example, Kellett and Warner (2011) identified the "social space" of Australian soccer umpires as a significant factor that raised their self-esteem; it functioned by highlighting accomplishments and by prompting them to share stories about their recent times on the field. Parsons and Bairner (2015) suggest that national governing bodies (NGBs) should harness the informal nature of referees' existing social networks.

Second, this study revealed that a high level of internal motivation reduced referees' work-family conflict. Although soccer referees do not tend to belong to a designated coach like athletes, instructors and assessors can be thought of as "coaches" for referees due to the similarity of their roles. A "motivational climate" enhances the level of intrinsic motivation because referees in such a setting tend to invest in the activity more for its own sake than as a means to an end (Amorose, 2007: 217). Discussion-based classroom techniques lead referees to feel that they actually learned something they will be able to implement during their next match and that their time and effort is being rewarded.

Hein and Koka (2007) argued that positive and informative feedback from physical education teachers can increase students' intrinsic motivation. This suggests that the feedback provided by referee coaches needs to be constructive rather than destructive, and it also needs to contain a substantive message. Referee coaches also need to inspire referees by pointing to the targets that individual referees can aim, monitoring referees' performance on a regular basis, and emphasizing the importance of team work, especially in the field of play, so that the internal motivation of referees is elevated.

Finally, the results provided empirical evidence for the proposition that internal motivation fully mediates the relationship between perceived organizational support and work-family conflict. As Chaturvedi (2008) has argued, highly motivated employees use their abilities to improve not only the effectiveness of the organization, but also the quality of their own life. Internal motivation helps employees to reduce their work-family conflict at an individual level. Even if they are irritated or busy with two domains (work and life), they feel socially engaged and free to choose how and when to engage in social activities. This suggests that referees with a high level of internal motivation feel that they have more self-determination in their refereeing role and are able to balance their soccer career and family.

This result supports Deci and Ryan's causality orientation theory. The theory argues that individuals reinterpret external stimuli according to their motivational orientation. While the external environment may present objective conflict, individuals with internal motivation do not perceive it because they reinterpret stressors simply as information (Deci \& Ryan, 1985). Internal motivational orientation can be viewed as the ability to recover rapidly from psychological distress or conflict, including work-family conflict, and the ability 
to control one's temper and handle difficulties rationally (Hur, Van den Berg, \& Wilderom, 2011). Internal motivation enables people to channel the direction of their motivation, which ultimately affects their perceptions of conflict and the imbalance between work and life. As a result, intrinsic motivation played a fully mediating role between perceived organizational support and work-family conflict of referees; perceived organizational support is not sufficient by itself, but can reduce work-family conflict through intrinsic motivation.

\section{Conclusion and limitation}

This study contributes to the sport management literature by offering the first attempt to investigate the relationship between perceived organizational support, internal motivation, and work-family conflict among referees, particularly in the Asian context. Nevertheless, some limitations should be pointed out when interpreting the results.

First, the study used self-reported data which can be one of the main sources of measurement error. To address this concern, Harman's single- factor test was used to investigate common method biases. However, such a test cannot resolve all the issues involved in measurement error. Future study should consider getting items from different longitudinal study and so on.

Second, the model was tested on a sample drawn from Korean referees only. Thus, special caution is advised when generalizing the results to other samples, as they may embody different traits.

Third, in this study internal motivation fully mediates the relations between perceived organizational support and work-family conflict. However, there could be another mechanism and reasoning process. For example, some referees who receive a high level of perceived organizational support could take the support for granted or act selfishly, having a negative impact on family life. Therefore, more research is needed to determine the causal relationships between perceived organizational support, internal motivation, and work-family conflict.

Finally, the result showed that perceived organizational support has a cascading effect on individual motivation and the level of work-family conflict; however, there could be a different chain of causation among perceived organizational support, internal motivation, and work-family conflict. Therefore, future research is needed to determine whether there is another causal chain or another set of causal relations obtains among the variables. 


\section{References}

Amorose, A. J. (2007). Coaching effectiveness. In M. S. Hagger \& N. L. D. Chatzisarantis (Eds.), Intrinsic motivation and self-determination in exercise and sport (pp. 209-227). Champaign, IL: Human Kinetics.

Australian Bureau of Statistics (2002). Involvement in organised sport and physical activity. Cat. No. 6285.0, Canberra; Commonwealth of Australia.

Auger, D., Fortier, J., Thibault, A., Magny, D., \& Gravelle, F. (2010). Characteristics and motivations of sports officials in the Province of Québec. International Journal of Sport Management Recreation \& Tourism, 5(b), 29-50.

Barnett, R. C. (2004). Women and multiple roles: Myths and reality. Harvard Review of Psychiatry, 12(3), $158-164$.

Berrar, D., Lopes, P., \& Dubitzky, W. (2017). Caveats and pitfalls in crowd sourcing research: the case of soccer referee bias. International Journal of Data Science and Analytics, 4(2), 143-151.

Blau, P. M. (1964). Exchange and power in social life. New York, NY: Wiley.

Buraimo, B., Forrest, D. \& Simmons, R. (2019). The Twelfth Man? Refereeing Bias in English and German Soccer. Journal of the Royal Statistical Society, 173(2), 431-449.

Carlson, D. S., \& Kacmar, K. M. (2000). Work-family conflict in the organization: Do life role values make a difference? Journal of Management, 26(5), 1031-1054.

Chaturvedi, V. (2008). Employees' empowerment: A key to intrinsic motivation. Management Articles, Articles and Papers by Faculty of Management Institutes.

Clark, S. C. (2000). Work/family border theory: A new theory of work/family balance. Human Relations, 53(6), $747-770$.

Clary, E. G., Snyder, M., Ridge, R. D., Copeland, J., Stukas, A. A., Haugen, J., \& Meine, P. (1998). Understanding and assessing the motivations of volunteers: A functional approach. Journal of Personality and Social Psychology, 74(6), 1516-1530.

Cordova, D. I., \& Lepper, M. R. (1996). Intrinsic motivation and the process of learning: Beneficial effects of contextualization, personalization, and choice. Journal of Educational Psychology, 88(4), 715-730.

Cunningham, I., \& Simmons, P. (2014). Skilled interaction: Concepts of communication and player management in the development of sport officials. International Journal of Sport Communication, 7(2), 166-187.

Cuskelly, G., \& Hoye, R. (2013). Sport officials' intention to continue. Sport Management Review, 
$16(4), 451-464$.

Cuskelly, G. (2004). Volunteer retention in community sport organisations. European Sport Management Quarterly, 4(2), 59-76.

Deci, E. L., \& Ryan, R. M. (1985). Intrinsic motivation and self-determination in human behavior. New York, NY: Plenum.

Demerouti, E. (2006). Job characteristics, flow, and performance: the moderating role of conscientiousness. Journal of Occupational Health Psychology, 11(3), 266-280.

Dixon, M. A., \& Bruening, J. E. (2005). Perspectives on work-family conflict in sport: An integrated approach. Sport Management Review, 8(3), 227-253.

Duong, D., Tuckey, M.R., Hayward, R.M., \& Boyd, C.M. (2015). Work-family conflict: The importance of differentiating between different facets of job characteristics, Work \& Stress, 29(3), 230-245.

Eaton, S. C. (2003). If you can use them: Flexibility policies, organizational commitment, and perceived performance. Industrial Relations, 42(2), 145-167.

Eisenberger, R., Huntington, R., Hutchison, S., \& Sowa, D. (1986). Perceived organizational support. Journal of Applied Psychology, 71(3), 500-507.

Frone, M. R., Russell, M., \& Cooper, M. L. (1992). Antecedents and outcomes of work-family conflict: Testing a model of the work-family interface. Journal of Applied Psychology, 77(1), 65-78.

Gagné, M., \& Deci, E. L. (2005). Self-determination theory and work motivation. Journal of Organizational Behavior, 26(4), 331-362.

Gagné, M., Forest, J., Gilbert, M.-H., Aubé, C., Morin, E., \& Malorni, A. (2010). The Motivation at Work Scale: Validation evidence in two languages. Educational and Psychological Measurement, 70(4), 628646.

Gagné, M.,Ryan, R. M., \& Bargmann, K. (2003). Autonomy support and need satisfaction in the motivation and well-being of gymnasts. Journal of Applied Sport Psychology, 15(4), 372-390.

Gillet, N., Vallerand, R. J., Amoura, S., \& Baldes, B. (2010). Influence of coaches' autonomy support on athletes' motivation and sport performance: A test of the hierarchical model of intrinsic and extrinsic motivation. Psychology of Sport and Exercise, 11(2), 155-161.

Gouldner, A. W. (1960). The norm of reciprocity. American Sociological Review, 25(2), 161-178.

Greenhaus, J. H., \& Beutell, N. J. (1985). Sources of conflict between work and family roles. Academy of Management Review, 10(1), 76-88. 
Greenhaus, J. H., Collins, K. M., \& Shaw, J. D. (2003). The relation between work-family balance and quality of life. Journal of Vocational Behavior, 63(3), 510-531.

Hair, J. F., Anderson, R. E., Tatham, R. L., \& Black, W. (1992). Multivariate data analysis with readings. (3rd ed.). New York, NY: Macmillan Publishing Company.

Hein, V. H., \& Koka, A. (2007). Perceived feedback and motivation in physical education and physical activity. In M. S. Hagger \& N. L. D. Chatzisarantis (Eds.), Intrinsic motivation and selfdetermination in exercise and sport (pp. 209-227). Champaign, IL: Human Kinetics.

Hong, E., \& Kim, S. H. (2013). The effects of football referees' organizational climate on job satisfaction and turnover intention. The Korean Journal of Physical Education, 52(5), 425-435.

Hur, Y. H., Van den Berg, P., Wilderom, C. P. M. (2011). Transformational leadership as a mediator between emotional intelligence and team outcomes. Leadership Quarterly, 22(4), 591-603.

Johansen, B.T. (2015). Reasons for officiating soccer: the role of passion-based motivations among Norwegian elite and non-elite referees. Movement \& Sport Sciences, 87, 23-30.

Jöreskog, K., \& Sörbom, D. (1993). LISREL 8: Structural equation modeling with the SIMPLIS command language. Chicago, IL: Scientific Software International Inc.

Kellett, P., \& Warner, S. (2011). Creating communities that lead to retention: The social worlds and communities of umpires. European Sport Management Quarterly, 11(5), 471-494.

Kim, H. K. (2014). Work-Life Balance and Employees'Performance: The Mediating Role of Affective Commitment. Global Business and Management Research: An International Journal, 6(1), 37-51.

Kim, M. C., \& Hong, E. (2016). A red card for women: Female officials ostracized in South Korean football. Asian Journal of Women's Studies, 22(2), 114-130.

Kim, S. (2017). Perceived organizational support as a mediator between distributive justice and sports referees' job satisfaction and career commitment. Annals of Leisure Research, 20(2), 169-187.

Korea Football Association (2018a). Elementary, middle and high school league. Retrieved from http://www.kfa.or.kr/league/league_school.asp

Korea Football Association (2018b). Statistics of registered referees in 2017 and 2018. Internal document, Korea Football Association.

Lamm, E., Tosti-Kharas, J., \& King, C. E. (2014). Empowering employee sustainability: Perceived organizational support toward the environment. Journal of Business Ethics, 128(1), 207-220.

Lim, D. H., Song, J. H. \& Choi, M. (2012). Work-family interface: Effect of enrichment and conflict on job performance of Korean workers. Journal of Management \& Organization, 18(3), 383-397. 
Loi, R., Hang-Yue, N., \& Foley, S. (2006). Linking employees' justice perceptions to organizational commitment and intention to leave: The mediating role of perceived organizational support. Journal of Occupational and Organizational Psychology, 79 (1), 101-120.

MacIntosh, E. W., \& Doherty, A. (2010). The influence of organizational culture on job satisfaction and intention to leave. Sport Management Review, 13(2), 106-117.

Mauno, S., \& Kinnunen, U. (1999). Job insecurity and well-being: A longitudinal study among male and female employees in Finland. Community, Work \& Family, 2(2), 147-171.

Mitchell, J. I., Gagné, M., Beaudry, A., \& Dyer, L. (2012). The role of perceived organizational support, distributive justice and motivation in reactions to new information technology. Computers in Human Behavior, 28(2), 729-738.

Mitchell, K. S. (2013). Low income: Risk of divorce. In Robert E. Emery (Ed.), Cultural Sociology of Divorce: An Encyclopedia. Thousand Oaks, CA: SAGE Publications, Inc.

Mulaik, A. A., James, L. R., Alstine, J. V., Lind, S., \& Stilwell, C. D. (1989). Evaluation of goodness-of-fit indices for structural equation modeling. Psychological Bulletin, 105(3), 430-445.

Netemeyer, R. G., Boles, J. S., \& McMurrian, R. (1996). Development and validation of work-family conflict and family-work conflict scales. Journal of Applied Psychology, 81(4), 400-410.

Nevill, A. M., Hemingway, A., Greaves, R., Dallaway, A., \& Devonport, T. J. (2017). Inconsistency of decision-making, the Achilles heel of referees. Journal of sports sciences, 35(22), 2257-2261.

Nunnally, J. C., \& Bernstein, I. H. (1994). Psychometric theory (3rd ed.). New York, NY: McGraw-Hill.

Parsons, T., \& Bairner, A. (2015). 'You want the buzz of having done well in a game that wasn’t easy': a sociological examination of the job commitment of English football referees. Movement and Sport Sciences- Science and Motricité, 87(1), 41-52.

Pelletier, L., Fortier, M., Vallerand, R., \& Brière, N. (2001). Associations among perceived autonomy support, forms of self-regulation, and persistence: a prospective study. Motivation and Emotion, 25(4), 279-306.

Philippe, F. L., Vallerand, R. J., Andrianarisoa, J., \& Brunel, P. (2009). Passion in referees: Examining their affective and cognitive experiences in sport situations. Journal of Sport \& Exercise Psychology, 31(1), 77-96.

Podsakoff, P. M., MacKenzie, S. M., Lee, J., \& Podsakoff, N. P. (2003). Common method biases in behavioral research: A critical review of the literature and recommended remedies. Journal of Applied Psychology, 88(5), 879-903. 
Ramos, R., Brauchli, R., Bauer, G., Wehner, T., \& Hammig, O. (2015). Busy yet socially engaged: Volunteering, work-life balance, and health in the working population. Journal of Occupational and Environmental Medicine, 57(2), 164-172.

Ridinger, L. L., Warner, S., Tingle, J. K., \& Kim, K. R. (2017). Why referees stay in the game. Global Sport Business Journal, 5(3), 22-37.

Rullang, C., Emrich, E. \& Pierdzioch, C. (2017). Why do referees end their careers and which factors determine the duration of a referee's career? Current Issues in Sport Science, 2, 1-13.

Ryan, R. M., \& Deci, E. L. (2000). Self-determination theory and the facilitation of intrinsic motivation, social development, and well-being. American Psychologist, 55(1), 68-78.

Séguin-Lévesque, C., Laliberté, M. L. N., Pelletier, L. G., Blanchard, C., \& Vallerand, R. J. (2003). Harmonious and obsessive passion for the internet: Their associations with the couple's relationship. Journal of Applied Social Psychology, 33(1), 197-221.

Seibert, S. E., Wang, G., \& Courtright, S. H. (2011). Antecedents and consequences of psychological and team empowerment in organizations: A meta-analytic review. Journal of Applied Psychology, 96(5), 981-1003.

Soares, J. T., \& Shamir, L. (2016). Quantitative analysis of penalty kicks and yellow card referee decisions in soccer. American Journal of Sports Science, 4(5), 84.

Sobel, M. E. (1982). Asymptotic confidence intervals for indirect effects in structural equations models. Sociological methodology, 13, 290-312.

Tremblay, M. A., Blanchard, C. M., Taylor, S., Pelletier, L. G., \& Villeneuve, M. (2009). Work extrinsic and intrinsic motivation scale: Its value for organizational research. Canadian Journal of Behavioural Science/Revue canadienne des sciences du comportement, 41(4), 213-226.

Vallerand, R. J. (1997). Toward a hierarchical model of intrinsic and extrinsic motivation. In M. P. Zanna (Ed.), Advances in experimental social psychology (pp. 271-360). New York, NY: Academic Press.

Vallerand, R. J. (2007). A hierarchical model of intrinsic and extrinsic motivation for sport and physical activity. In M. S. Hagger, \& N. L. D. Chatzisarantis (Eds.), Self-determination theory in exercise and sport(pp. 255-279). Champaign, IL: Human Kinetics.

Vernon, W. A. (2013). Factors responsible for work-life conflict: A study comparing the teaching and legal professions (Doctoral dissertation). Available from Electronic Thesis and Dissertation Repository (Paper 1167).

Voorde, K. V. D., Veldhoven, M. V., \& Paauwe, J. (2010). Time precedence in the relationship between 
organizational climate and organizational performance: A cross-lagged study at the business unit level. International Journal of Human Resource Management, 21(10), 1712-1732.

Webb, T. (2018). Referees and the media: a difficult relationship but an unavoidable necessity. Soccer \& Society, 19(2), 205-221.

Wu, C. C., \& Liu, N. T. (2014). Perceived organizational support, organizational commitment and service-oriented organizational citizenship behaviors. International Journal of Business and Information, 9(1), 61-88. 
Table 1. CFA loading values of measurement variables ${ }^{1)}$

\begin{tabular}{|c|c|c|c|c|c|}
\hline \multicolumn{2}{|l|}{ POS } & \multicolumn{2}{|l|}{ Internal Motivation } & \multicolumn{2}{|l|}{ WFC } \\
\hline $\begin{array}{l}\text { FA values my contribution to } \\
\text { its well-being }\end{array}$ & .62 & & & & \\
\hline $\begin{array}{l}\text { FA strongly considers my goals } \\
\text { and values }\end{array}$ & .69 & & & & \\
\hline $\begin{array}{c}\text { FA understands a long absence } \\
\text { due to my illness }\end{array}$ & .68 & & & & \\
\hline $\begin{array}{l}\text { Help is available from FA } \\
\text { when I have a problem }\end{array}$ & .75 & & & & \\
\hline $\begin{array}{l}\text { FA really cares about my } \\
\text { well-being }\end{array}$ & .78 & & & & \\
\hline $\begin{array}{c}\text { FA is willing to help me when I } \\
\text { need a special favor }\end{array}$ & .82 & & & & \\
\hline $\begin{array}{c}\text { FA cares about my general } \\
\text { satisfaction at work }\end{array}$ & .80 & & & & \\
\hline FA cares about my opinions & .64 & & & & \\
\hline $\begin{array}{c}\text { FA takes pride in my refereeing } \\
\text { accomplishments }\end{array}$ & .73 & & & & \\
\hline \multirow[t]{16}{*}{$\begin{array}{l}\text { FA tries to make my job as } \\
\text { interesting as possible }\end{array}$} & .77 & & & & \\
\hline & & $\begin{array}{l}\text { Refereeing makes me feel an } \\
\text { important human being }\end{array}$ & .73 & & \\
\hline & & $\begin{array}{c}\text { Refereeing increases my } \\
\text { self-esteem }\end{array}$ & .70 & & \\
\hline & & $\begin{array}{c}\text { There are things I can learn } \\
\text { through refereeing }\end{array}$ & .65 & & \\
\hline & & $\begin{array}{c}\text { I referee because I can do } \\
\text { something important }\end{array}$ & .72 & & \\
\hline & & $\begin{array}{c}\text { Refereeing makes me think in } \\
\text { a more favorable way about } \\
\text { me }\end{array}$ & .77 & & \\
\hline & & $\begin{array}{c}\text { Refereeing makes me explore } \\
\text { my strength }\end{array}$ & .66 & & \\
\hline & & & & $\begin{array}{l}\text { Refereeing interferes with my } \\
\text { family life }\end{array}$ & .79 \\
\hline & & & & $\begin{array}{l}\text { I face difficulties due to the } \\
\text { time I spend on refereeing }\end{array}$ & .81 \\
\hline & & & & $\begin{array}{l}\text { I can't undertake my duties at } \\
\text { home due to referee activity }\end{array}$ & .78 \\
\hline & & & & $\begin{array}{l}\text { Refereeing affects my home } \\
\text { duties negatively }\end{array}$ & .78 \\
\hline & & & & $\begin{array}{l}\text { Obligations from home } \\
\text { interferes with my refereeing }\end{array}$ & .76 \\
\hline & & & & $\begin{array}{c}\text { I have to postpone refereeing } \\
\text { activity because of home } \\
\text { duties }\end{array}$ & .69 \\
\hline & & & & $\begin{array}{l}\text { Refereeing does not get } \\
\text { finished due to issues at home }\end{array}$ & .67 \\
\hline & & & & $\begin{array}{c}\text { I can't perform refereeing duty } \\
\text { due to matters at home }\end{array}$ & .61 \\
\hline & & & & $\begin{array}{l}\text { Tension at home interferes } \\
\text { with my development as a } \\
\text { referee }\end{array}$ & .68 \\
\hline
\end{tabular}

1) Completely standardized solution 
Table 2. Means, Standard Deviations, Reliability, and Correlations among the Key Variables $(\mathbf{N}=\mathbf{2 6 0})^{12)}$

\begin{tabular}{|l||c|c||c|c|c|}
\hline & Mean & S.D. & (1) & (2) & (3) \\
\hline \hline (1) POS & 4.36 & 1.18 & $(.918)$ & & \\
\hline (2) Internal motivation & 5.25 & 1.09 & $.286 * *$ & $(.853)$ & \\
\hline (3) WFC & 2.38 & .86 & $-.181 * *$ & $-.257 * *$ & (.913) \\
\hline
\end{tabular}

1) **: $\mathrm{p}<.01:$ two tailed test

2) Reliability coefficient is in parentheses 
Table 3. Means, Standard Deviations, and Correlations among the Control Variables $(\mathbf{N}=260)^{1)}$

\begin{tabular}{|c|c|c|c|c|c|c|c|c|c|c|c|}
\hline & Mean & $\mathrm{SD}$ & (1) & (2) & (3) & (4) & (5) & (6) & (7) & (8) & (9) \\
\hline (1) $\mathrm{Sex}^{2}$ & .89 & .32 & 1 & & & & & & & & \\
\hline (2) Age & 33.69 & 9.14 & $.280 * *$ & 1 & & & & & & & \\
\hline (3) Educational level ${ }^{3)}$ & 3.29 & 1.04 & .027 & $.145^{*}$ & 1 & & & & & & \\
\hline (4) Career Experience in years & 6.40 & 3.96 & $-.166 * *$ & $.426 * *$ & $.215^{* *}$ & 1 & & & & & \\
\hline $\begin{array}{l}\text { (5) Monthly income excluding } \\
\text { refereeing fee }\end{array}$ & 2.33 & 1.33 & $.255 * *$ & $.694 * *$ & $.175^{* *}$ & $.262 * *$ & 1 & & & & \\
\hline $\begin{array}{l}\text { (6) Monthly income from refereeing } \\
\text { fee }\end{array}$ & 1.51 & .855 & -.005 & $.129 *$ & .053 & $.440 * *$ & .073 & 1 & & & \\
\hline (7) Match numbers per month & 8.54 & 4.65 & -.117 & $-.314 * *$ & -.123 & -.131 & $-.273 *$ & .107 & & & \\
\hline (8) Marital status ${ }^{5}$ & .41 & .50 & $.154 *$ & $.737 * *$ & .004 & $.257^{* *}$ & $.586^{* *}$ & .069 & $-.273 * *$ & 1 & \\
\hline (9) Current level of refereeing ${ }^{6}$ ) & 3.02 & .924 & .019 & $.186^{* *}$ & $.242 * *$ & $.697 * *$ & .091 & $.471 * *$ & -.072 & .046 & 1 \\
\hline
\end{tabular}

1) $* \mathrm{p}<.05, * *: \mathrm{p}<.01:$ two tailed test

2) Female $=0$, Male $=1$

3) Under high school graduate $=1$, High school graduate $=2$, College graduate $=3$, University graduate $=4$, Masters or Ph. $\mathrm{D}=5$

4) Below 0.5 million $\mathrm{KRW}=1,0.5 \sim 1$ million $\mathrm{KRW}=2,1 \sim 1.5$ million $\mathrm{KRW}=3,1.5 \sim 2$ million $\mathrm{KRW}=4,2 \sim 2.5$ million $\mathrm{KRW}=5$, Over 2.5 million $\mathrm{KRW}=6$

5) Unmarried $=0$, Married $=1$

6) $4^{\text {th }}$ class $=1,3^{\text {rd }}$ class $=2,2^{\text {nd }}$ class $=3,1^{\text {st }}$ class $=4$ 
Table 4. Standardized LISREL Coefficient Estimates for the Causal Model $(\mathrm{N}=\mathbf{2 6 0})^{1)}$

\begin{tabular}{|c|c|c|}
\hline & Internal Motivation & WFC \\
\hline \multicolumn{3}{|l|}{ Control variables: } \\
\hline $\operatorname{Sex}^{2)}$ & -.02 & .02 \\
\hline Age & .15 & .11 \\
\hline Educational level $^{3)}$ & .02 & .08 \\
\hline Career experience in years & .03 & .04 \\
\hline Monthly income excluding refereeing fee ${ }^{4)}$ & .06 & -.03 \\
\hline Monthly income from refereeing fee ${ }^{4)}$ & -.02 & .10 \\
\hline Number of matches per month & -.06 & .00 \\
\hline Marital status ${ }^{5}$ & -.09 & .00 \\
\hline Current level of refereeing $\left.{ }^{6}\right)$ & .00 & $.15^{\dagger}$ \\
\hline \multicolumn{3}{|l|}{ Exogenous variables: } \\
\hline POS & $.32 * * *$ & \\
\hline$\frac{\text { Mediating variables: }}{\text { Internal motivation }}$ & & $-.28 * * *$ \\
\hline Goodness of Fit Statistics & $\begin{array}{r}\chi^{2} \\
C F I=1.00, I F I= \\
G F I=1.00, A\end{array}$ & $\begin{array}{l}N N F I=1.00 \\
.0057\end{array}$ \\
\hline
\end{tabular}

1) $\dagger:<.10, * * *: \mathrm{p}<.001:$ two tailed test

2) Female $=0$, Male $=1$

3) Under high school graduate $=1$, High school graduate $=2$, College graduate $=3$, University graduate $=4$, Masters or $\mathrm{Ph}$. $\mathrm{D}=5$

4) Below 0.5 million $\mathrm{KRW}=1,0.5 \sim 1$ million $\mathrm{KRW}=2,1 \sim 1.5$ million $\mathrm{KRW}=3,1.5 \sim 2$ million $\mathrm{KRW}=4$,

$2 \sim 2.5$ million $\mathrm{KRW}=5$, Over 2.5 million $=6$

5) Unmarried $=0$, Married $=1$

6) $4^{\text {th }}$ class $=1,3^{\text {rd }}$ class $=2,2^{\text {nd }}$ class $=3,1^{\text {st }}$ class $=4$ 